\title{
In Quest of Genocide Understanding: Multiple Faces of Genocide
}

\author{
Aleksandra Matulewska ${ }^{1}$ (D) - Dariusz J. Gwiazdowicz ${ }^{2}$ (D)
}

Accepted: 13 April 2021 / Published online: 11 May 2021

(c) The Author(s), under exclusive licence to Springer Nature B.V. 2021

\begin{abstract}
The paper focuses on genocide and its multidimensional emanations. First, the authors present the definition of genocide and its types as elaborated by Lemkin (Axis rule in occupied Europe: laws of occupation, analysis of government, proposals for redress. Carnegie Endowment for International Peace Division of International Law, Columbia University Press, Washington, DC, New York, 1944): physical, political, social, cultural, economic, biological, religious, and finally moral genocide. Next, ten stages of genocide by Stanton (Genocide Watch, 2016) are scrutinized with some emphasis placed on the verbal issues enabling polarization and dehumanization. The authors point out that modern means of communication, ubiquitous nowadays, make it possible to dehumanize and discriminate against groups of people on an unprecedented scale. Therefore, hate speech and infodemic spread on the Internet, especially social media may be a skillfully used tool of lynch and genocide incitement.
\end{abstract}

Keywords Genocide - Types of genocide $\cdot$ Stages of genocide $\cdot$ Extermination · Annihilation · Dehumanization · Hate speech · Cyberbullying · Polarization · Discrimination

\section{Introduction}

Genocide is a multifaceted atrocity. It is committed by ordinary people, having normal, loving families, who step by step change their attitude towards some other groups of people. Thus, genocide is a long-lasting process of indoctrination, brain washing and dehumanization. Furthermore, the process of dehumanization

Aleksandra Matulewska

aleksandra.matulewska@gmail.com

1 Collegium Novum, Faculty of Modern Languages and Literatures, Adam Mickiewicz University, Al. Niepodległości 4, Block A Room 107, 61-874 Poznan, Poland

2 Department of Forest Protection, Collegium Maximum, Faculty of Forestry, Poznań University of Life Sciences, Wojska Polskiego 28, 60-637 Poznan, Poland 
is a two-step process - it is the dehumanization of victims and the oppressors who convert from common people to beasts able to persecute, torture and kill other human beings. The multifaceted nature of genocide stems from the fact that it encompasses not only deeds but also words in action. First, the words are used to classify and polarize groups of people. Next, the avalanche effect occurs and the acts of brutality, cruelty, bestiality follow. As it turns out human beings are incredibly creative as far as inflicting harm to others is concerned. Therefore, the acts of genocide and the path to this hideous crime encompass a wide variety of actions, which may not be detected as dangerous at an early stage. It is due to the fact that genocide does not need to start with the act of life deprivation. Thus, the authors will try to answer the question how genocide is understood as well as what its types and stages are. Furthermore, the semantic aspect of genocides will be scrutinized.

\section{How Do We Understand Genocide, its Types and Stages?}

The term genocide was coined by a Polish professor of law, Raphael Lemkin in the course of the Second World War atrocities in his work published in 1944 as a blend of the Greek genos meaning 'race or tribe' and the Latin cide meaning 'killing'. Lemkin defined genocide as follows:

[...] Generally speaking, genocide does not necessarily mean the immediate destruction of a nation, except when accomplished by mass killings of all members of a nation. It is intended rather to signify a coordinated plan of different actions aiming at the destruction of essential foundations of the life of national groups, with the aim of annihilating the groups themselves. The objectives of such a plan would be the disintegration of the political and social institutions, of culture, language, national feelings, religion, and the economic existence of national groups, and the destruction of the personal security, liberty, health, dignity, and even the lives of the individuals belonging to such groups [28: 79].

Lemkin [27] analyzed genocide not only as life deprivation but also as the deprivation of a group of people of means of survival and preservation of their identity. Therefore, he distinguished eight aspects of genocide:

(i) physical,

(ii) political,

(iii) social,

(iv) cultural,

(v) economic,

(vi) biological,

(vii) religious, and finally

(viii) moral. 
Having analyzed the atrocities of Nazi he observed that for the eradication of a group of people one needed to deprive them of their resources, heritage, identity, hope and finally lives.

The easiest to observe and most condemnable is certainly the deprivation of humans of their lives which constitutes the essence of physical genocide. It may be conducted in a variety of ways, starting with food rationing, limiting access to healthcare and ending with mass killings. Nevertheless, it is actually the final stage of genocide which is usually preceded by other abovementioned stages [28: 79-95]. But the act of shooting someone is a short-lasting killing, whereas condemning people to malnutrition, starvation and health devastation is a long-lasting process of life deprivation. At the initial stages the latter is less visible, less difficult to identify.

The society, which is subjected to genocide preparation stage usually, is forced to accept the changes at the level of local self-government and other administrative structures. The occupying nation or dominant ruling group impose their own governmental units. Besides, the right to use a native language in public spaces is limited or banned. The signs, information leaflets and other inscriptions are unified and formulated in the language imposed by the dominant group. That type of genocide is called political genocide by Lemkin [27: 79-95].

The political genocide is strictly related to the social one as the latter involves the replacement of judicature structures with the occupying nation's judicial system [27: 79-95].

Another important element of genocide is the deprivation of a group of people of their culture, opportunities and possibilities of preserving their cultural heritage and traditions. According to Lemkin [28]:

The cultural genocide involved eradicating the native language from public life and strictly controlling and censoring the activities of journalists and artists engaged in painting, drawing, sculpture, music, literature, and the theater. It also involved stealing and destroying works of art such as books, paintings, sculptures, etc. It also encompassed destroying archives [28: 79-95]. [22]

As a result of limiting the access of members of society belonging to various social strata to numerous types of jobs, professions, activities, the economic genocide follows. In general, the standard of living of persons subjected to genocide deteriorates rapidly. People need to increase their chances of physical survival, fighting against famine and starvation. Therefore, they no longer can participate in social and cultural life [28: 79-95]. They fight to satisfy only the basic needs from the bottom layer of Maslow's pyramid, which at a certain stage becomes less and less performable due to numerous restrictions of various sorts imposed on them. As a result, the problems of malnutrition and rapid health deterioration appear very frequently. It, in turn, leads to the biological genocide. The dominant nation can enjoy wealthy life whereas the oppressed nation is no longer able to provide a decent standard of living to their children. As a result, birth rates of the former increase and of the latter drop [28: 79-95].

As the extermination of the nation may be conducted in a variety of ways, one of the most important issues is the deprivation of people of their identity 
at various levels. As religion provides people with hope and strength to survive hardships of life, the persecution of clergymen, laicization and destruction of places of prayer constitutes the religious genocide [28: 79-95] no matter the denomination of the group. It is also connected with the process of the eradication of intelligentsia as the clergymen are usually well-educated persons.

Once the nation, or social group are deprived of their dignity, religion, resources of survival, the path is waved to the moral genocide that is to say the degeneration of the nation during which:

the mental energy of the group should be concentrated upon base instincts and should be diverted from moral and national thinking. It is important for the realization of such a plan that the desire for cheap individual pleasure be substituted for the desire for collective feelings and ideals based upon a higher morality. Therefore, the occupant made an effort in Poland to impose upon the Poles pornographic publications and movies. The consumption of alcohol was encouraged, for while food prices have soared, the Germans have kept down the price of alcohol, and the peasants are compelled by the authorities to take spirits in pay agricultural produce. The curfew law, enforced very strictly against Poles is relaxed if they can show the authorities a ticket to one of the gambling houses which the Germans have allowed to come into existence [28: 90].

The more desperate and depressed people are, the more susceptible they become to various kinds of addictions and cheap joys of life. They crave to forget about the hardships of their life even if it is going to be very temporary. The moment of oblivion is craved for, and all sorts of intoxicants, adrenaline-boosters or designer drugs may be used to achieve that aim. They sedate hunger, bring relaxation and artificial good mood. They enable to forget about the reality for a moment. Additionally, when facing death, the negative side-effects are no longer important, as people do not think they are going to live long enough to suffer from them.

Genocide may be approached from other angles too. It is worth mentioning here ten stages of genocide developed by Gregory Stanton [41]:

(i) classification,

(ii) symbolization,

(iii) discrimination,

(iv) dehumanization,

(v) organization,

(vi) polarization,

(vii) preparation,

(viii) persecution,

(ix) extermination, and

(x) denial.

The first stage, which is called classification is the division of the society into two bipolar groups, e.g. German and Jew. The limited integration between the groups 
and their separation from each other make it more probable for genocide to follow. Once the society is classified, the symbolization may follow [41]. The symbolization is the process of giving labels to two groups. The stage of symbolization, from the perspective of linguistics involves stereotyping cf. [3, 11,32]. The stage of discrimination by Stanton [41] in fact encompasses Lemkin's political, social and economic genocides.

A dominant group uses law, custom, and political power to deny the rights of other groups. The powerless group may not be accorded full civil rights, voting rights, or even citizenship. The dominant group is driven by an exclusionary ideology that would deprive less powerful groups of their rights. The ideology advocates monopolization or expansion of power by the dominant group. It legitimizes the victimization of weaker groups. Advocates of exclusionary ideologies are often charismatic, expressing resentments of their followers, attracting support from the masses. Examples include the Nuremberg Laws of 1935 in Nazi Germany, which stripped Jews of their German citizenship, and prohibited their employment by the government and by universities. Denial of citizenship to the Rohingya Muslim minority in Burma is a current example.

Stanton [41] rightly emphasizes the stage of dehumanization as one of the most important ones as people belonging to one group "are equated with animals, vermin, insects or diseases. Dehumanization overcomes the normal human revulsion against murder." What is more, the language plays a crucial role in this process as "hate speech fills the propaganda of official radio, newspapers, and speeches." [41] One should point out here that at present the new phenomenon called cyberbullying makes the implementation of that stage incredibly easy and fast [10, 16, 24, 42].

Genocide actions are formally or informally organized. The stage of organization may be carried out by a group of volunteers or by militia, army units, etc. Nevertheless, the group of people must be trained how to destroy or kill. The stage of polarization is actually the enhanced operation of dehumanization [23] as it involves more intense hate speech spreading cf. [5, 8, 20, 38]. "Hate groups broadcast polarizing propaganda. Motivations for targeting a group are indoctrinated through mass media." [41]. The stage of preparation is the prelude to the final act of killing. Perpetrator group leaders continue training and equipping their "soldiers" with weapon and other tools. People are scared with the other group. They are taught to perceive them as bloodthirsty and dangerous for the society. "There is a sudden increase in inflammatory rhetoric and hate propaganda with the objective of creating fear of the other group." [41]. The stage of persecution may follow freely. People are exposed to biological and economic genocide. The access to food and other resources is limited. They are no longer members of society. They are put on the black list of pests. They become pariahs, vermin that need to be eliminated and that in fact happens at the stage of extermination. After the killing, the stage of denial follows which is characterized by not taking responsibility for the committed atrocities. There may be blame shifting, blame diminishing or complete denial of the genocide [41], cf. also $[9,12]$.

As Stanton [41] claims the stages should not be treated as obligatorily present at every act of genocide. What is more, they may occur simultaneously or 
consecutively as genocide is a process spread in time and space [37] rather than a short-term, one-off event.

The atrocities of the Second World War turned out to be scary and condemnable to the extent which resulted in international laws enacted to prevent such crimes. Due to the Convention on the Prevention and Punishment of the Crime of Genocide signed on 9 December 1948 [14], "genocide" coined by Lemkin became a legal term. In the original version of the 1946 Convention (to be exact the United Nations General Assembly Resolution 96 of 11 December 1946, titled "The Crime of Genocide" [45]), the definition also included crimes committed for "political" reasons, but these were removed due to pressure from, inter alia, the Soviet Union, possibly because of Joseph Stalin's fear of legal liability. Article 2 of the Convention [14] defines genocide as.

[...] any of the following acts committed with intent to destroy, in whole or in part, a national, ethnic, racial or religious group, as such:

(a) killing members of the group;

(b) causing serious bodily or mental harm to members of the group;

(c) deliberately inflicting on the group conditions of life calculated to bring about its physical destruction in whole or in part;

(d) imposing measures intended to prevent births within the group;

(e) forcibly transferring children of the group to another group.

This Convention [14] indicates that what is punishable is not only genocide, but also inciting, complicity, attempting to commit it, and collusion to commit it. In order to effectively prosecute the crime of genocide, the punishment was provided for the guilty ones regardless of whether they would exercise state functions. Punishing for the crime of genocide has been entrusted to the internal judiciary of the member states of the Convention and to the international judiciary, provided that the state is a member of the system. The UN Convention on the Non-Applicability of Statutory Limitations to War Crimes and Crimes Against Humanity of 26 November 1968 [13] lists genocide as a crime that cannot be time-barred.

Genocide is frequently connected with the eradication of indigenous people by the invading oppressors. In the light of the United Nations Declaration on the Rights of Indigenous Peoples (UNDRIP) [44] which was adopted by the General Assembly on Thursday, 13 September 2007 and which is a benchmark for delineating the modern meaning of genocide we may state that numerous groups can be classified as the indigenous people living at some soil. Their rights are specified under article 7 :

Article 7

1. Indigenous individuals have the rights to life, physical and mental integrity, liberty and security of person.

2. Indigenous peoples have the collective right to live in freedom, peace and security as distinct peoples and shall not be subjected to any act of genocide or any other act of violence, including forcibly removing children of the group to another group. 
If someone is forced to live their homes having just several minutes to pack most important things, leaving behind their belongings, family memoires and land they love they are subjected to genocide. Such practices are condemnable too:

Article 10

Indigenous peoples shall not be forcibly removed from their lands or territories. No relocation shall take place without the free, prior and informed consent of the indigenous peoples concerned and after agreement on just and fair compensation and, where possible, with the option of return.

Moreover, in article 8 we read about cultural genocide as defined by Lemkin:

Article 8

1. Indigenous peoples and individuals have the right not to be subjected to forced assimilation or destruction of their culture.

2. States shall provide effective mechanisms for prevention of, and redress for:

(a) Any action which has the aim or effect of depriving them of their integrity as distinct peoples, or of their cultural values or ethnic identities;

(b) Any action which has the aim or effect of dispossessing them of their lands, territories or resources;

(c) Any form of forced population transfer which has the aim or effect of violating or undermining any of their rights;

(d) Any form of forced assimilation or integration;

(e) Any form of propaganda designed to promote or incite racial or ethnic discrimination directed against them.

Even the forced assimilation of one group to the traditions and culture of others may constitute the act of genocide because the ability and opportunity to practice customs, cultivate traditions and preserve heritage are also important:

Article 9

Indigenous peoples and individuals have the right to belong to an indigenous community or nation, in accordance with the traditions and customs of the community or nation concerned. No discrimination of any kind may arise from the exercise of such a right.

Article 11

1. Indigenous peoples have the right to practise and revitalize their cultural traditions and customs. This includes the right to maintain, protect and develop the past, present and future manifestations of their cultures, such as archaeological and historical sites, artefacts, designs, ceremonies, technologies and visual and performing arts and literature.

Therefore, it can be assumed that the concept of genocide is not unambiguous and can be interpreted and used in multiple situations, also analyzed in various aspects of social life. It may apply to indigenous people, to ethnic groups, races but also other social groups such as professional groups or subcultures.

It is important to remember that the stages and types of genocide distinguished by Lemkin [28] and Stanton [41] are vital for identification of social trends which 
may end with the culmination stage of lynches, pogroms or genocide that is to say the physical acts of extermination. What seems to play a vital role in genocide which as it seems cannot be perceived solely as the eradication of ethnic groups, is language and images. Especially the stages of classification, symbolization, discrimination, dehumanization, and polarization involve the usage of verbal means and images to divide people into "us" and "them". Words and images become labels. Dehumanization which involves animalization opens the gate for degradation, mistreatment and denial of rights [23]. The animalization occurs via linguistic tools. Language signs are used to degrade human beings to despised animals. From that perspective, researchers, governments and leaders should monitor hate speech, bullying and cyberbullying practices [5, 20]. The narrow red line between the freedom of speech and hate speech should be identified and societies should be taught how to remain on the right side. The increasing literature on hate speech e.g. [5, 20] and cyberbullying [10, 16, 24, 30, 42, 43] shows that modern media and infodemic spread via them may pave the way to new forms of extermination affecting smaller than ethnic groups of society members who are perceived as not compliant with the modern image of the "righteous human being". What we observe nowadays is the discourse of tolerance on the one hand, and the discourse of hate speech on the other.

Hate speech, which is skillfully and used at the discrimination, dehumanization and preparation stages, is targeted at the group which is considered worse, deviant and pathological in some way [36, 39]. Indeed, the language expresses on biased opinions and resorts to picturesque stereotypes [3, 11, 32]. It aims at offending, humiliating, frequently by using vulgar or offensive language, as well as terminology associated with animals. The deviant group is the one which does not share our worldview, which contradicts our beliefs, opinions (also political ones) and morals (frequently religious). The rhetoric focuses on inciting fear, danger posed by "them", accusations of unpunished wrongdoings, mistreatment and crimes committed by them, and finally there are also threats. The intensity of the hate-based rhetoric increases gradually from the stage of classification, which may seem initially almost neutral, through symbolization, discrimination, achieving high intensity at the stages of dehumanization and polarization, and its peak at the stages of preparation and extermination. Initially, the language is characterized by implicit rhetoric, but with the course of time it becomes explicit. The more acceptance for the rhetoric of discrimination and exclusion among society members at each stage, the more intense and outspoken it becomes cf. $[1,4,31]$ and the higher probability that the extermination stage follows.

\section{Our Scopes on Multifaceted Aspects of Genocide}

Given the complex historical period or place in the world in which a genocide was perpetrated, many experts in the fields of history, social science, psychology, linguistics and law have investigated these issues. This special issue gave them the opportunity to express their opinions, to present the results of research on various aspects of this multithreaded topic. Issues covered therein include the reasons for our cruelty to 
others, the role of language as a tool of ostracism, discrimination and dehumanization, the social, professional and political reasons for genocide, the role of translators and interpreters in genocide trials and the importance of trials for victims.

\subsection{Why Are People Sometimes Murderously Cruel to Each Other?}

During the Second Sino-Japanese War between the Empire of Japan and the Republic of China, Japanese entered the city of Nanking on 13 December 1937. The slaughter of prisoners of war and civilians began, and Japanese soldiers were unimaginably cruel. Thousands of prisoners of war were shot with machine guns on the banks of the Yangtze River, and the bodies thrown into the river flowed all the way to Shanghai. However, the civilian population suffered the most. The Japanese committed rape, looting and murder on a massive scale with particular cruelty. The Nanking Massacre, also known as the Rape of Nanking, ended at the end of January 1938. At least 30,000 civilians, including thousands of women and children, lost their lives in this genocide. The crimes of the Japanese have been the subject of numerous historical and legal studies. They were also a source of inspiration for the production of historical films, the most famous of which is "Black Sun: The Nanking Massacre" from 1995 directed by Mou Tun-fei, also known as Men Behind the Sun 4. It was the Nanking massacre and the above-mentioned film that were the subject of considerations and analysis of $\mathrm{Hu}$ [25] who illustrated two contradictory discourses - justification and opposition to mass murder, or in other words its denial.

The author wonders how such a cruel crime could have happened and how Japanese soldiers justified their actions. After all, there were international conventions, rules of law that protected prisoners of war and civilians. It is true that the Japanese government did not ratify the Geneva Convention of 1929 [21], but soldiers were bound by the Japanese Army Criminal Codes, in which we read, inter alia:

Article 87: Soldiers, who plunder clothes and property from the dead, or the wounded, or the sick on the battlefield, shall be sentenced to an imprisonment of more than a year.

Article 88: If a soldier, who has committed the previous two crimes, hurts civilians, he shall be sentenced to an imprisonment of more than 7 years, or to an imprisonment up to lifetime. If a soldier kills civilians, he will be sentenced to a lifetime imprisonment, or to the death penalty.

So why was there the permission for the crime? Why did the officers not react to the criminal offenses of their subordinates? "Black Sun: The Nanking Massacre" movie shows viewers how Japanese soldiers justified the killing of Chinese people based on the belief that if actions are for a good purpose, such as the well-being of the motherland, then such actions cannot be wrong. Meanwhile, a legitimate goal must be achieved through means or methods based on moral principles resulting from upbringing, culture of a given country or law. The film also explains why Japanese soldiers could cross the border of humanity and commit atrocities. It can be considered that it was the "Lucifer Effect" consisting in changing the character of a person from good to bad only because of external factors, the social environment 
in which the person found himself at a given moment. The social pressure seems to play a crucial role in such character transformations. The ubiquitous need to be a member of some group makes people act in a variety of ways, frequently justifying and legitimizing their wrongdoing [26].

The Nanking massacre is the example of crime in which the stage of denial [cf. 41] may also be distinguished. The author gives examples of statements by people who undermine historical facts and suggest that the Nanking massacre is a lie intended to degrade and shame Japan and the Japanese on the international arena. Meanwhile, admitting genocide is a necessary first step in honoring the victims.

\subsection{Language as a Tool of Ideological Struggle}

Margarete Flöter-Durr [19] in her paper titled Le discours de l'authenticité: de l'ensauvagement de la langue à l'anéantissement d'autrui, focuses on the linguistic aspect of genocide. The political and intellectual movement of the radical right that developed at the beginning of the twentieth century in the Weimar Republic was the "conservative revolution". The main inspiration was Artur Moeller van den Bruck (the creator of the term "Third Reich"), but also writers Thomas Mann and Ernst Jünger, a historian Oswald Spengler, a philosopher Martin Heidegger and a lawyer Carl Schmitt were also active. The intellectuals of this movement were characterized by a cultural pessimism condemning all forms of modernity, which was manifested, among others, by liberalism, pluralism, individualism and parliamentary democracy, that is, concepts disseminated in Europe since the French Revolution. Although some representatives of the "conservative revolution" did not identify themselves with the National Socialism, others, such as Heidegger and Schmitt, actively participated in its implementation and thus legitimized the racial community or the call to search for the enemy, both intellectual and political.

The National Socialism (Nationalsozialismus), sometimes also referred to as Nazism, was a fascist, racist, anti-communist, anti-democratic and anti-Semitic ideology advocated by the National Socialist German Workers' Party (Nationalsozialistische Deutsche Arbeiterpartei, NSDAP). In the years 1933-1945, when the NSDAP was in power, it was a state ideology based on militarism and chauvinism. At that time, the Nazis were carrying out their plans to exterminate the Jews. The Wannsee conference held on January 20, 1942 in Berlin played an important role. There, highranking government officials met to discuss the final solution to the Jewish question, as the genocide of the Jews had already begun to be described euphemistically.

The charisma of Adolf Hitler and his oratorical talent certainly helped the Nazis in achieving their goals. However, it is obvious that language, which can be a tool of manipulation, plays an important role in the ideological struggle. This is the problem that Flöter-Durr [19] examined when she analyzed discursive and linguistic strategies that had made it possible to anchor the world view of National Socialism in the political, philosophical and legal discourse in Germany in 1939-1945. She shows that the introduction of the racial criterion to the philosophical discourse and legal system profoundly changed the meaning of concepts, which allowed for the exclusion of a certain group of people and deeming them unworthy of belonging to 
the community of the Germanic people. Additionally, this language served to justify the genocide of Jews after 1945. Through semantic manipulations, the Nazis wanted to neutralize the evil done in public perception.

The author analyzed the term "authenticity" (Eigentlichkeit), which is a key word expressing the world view of the National Socialism in the works of Martin Heidegger. Linguistically, it is one of the most important newspeak terms of the Third Reich. It is the cornerstone of the semantic network, which allowed to articulate the vision of the world of National Socialism and bring it to for the self-determination of the commonwealth of the people, the vocation of the German race to dominate others, the designation of internal and external enemies. As a result, the Jews were instrumentalized, made foreigners who stood in opposition to the community of the people of Germany. There were two classes of citizen: "us" that is Germans and them that is "Jews" who were responsible for all manifestations of evil, therefore there was no need for dialogue but it was a straightforward justification for the extermination of Jews.

\subsection{Gender in the Discourse of Genocide Trials}

The next paper from Lyn Ellison and Natalia Szablewska [17] touches upon a very interesting issue of the participation of women in genocide from the perspective of their roles in society and the gender-affected discourse which is used in their trials. It focuses on sociolinguistic factors affecting the trials. Stereotypically women are perceived as sensitive and caring mothers, protectors and victims of violence. The historical and legal evidence, however, reveals that they may be soldiers, militia members, insurgents, terrorists, and participants of genocide atrocities. In the countries which enable women to join the army, their numbers grow steadily over time. Women undergo obligatory military training with men in Israel, they comprise from 11 to $18 \%$ of UK Regular Forces, United States military forces and Australian Defence. They are able to participate in combat and kill the enemies. Ellison and Szablewska [17] provide some insight into the high-profile cases of Biljana Plavšić at the International Criminal Tribunal for the former Yugoslavia (ICTY) and Pauline Nyiramasuhuko at the International Criminal Tribunal for Rwanda (ICTR).

Biljana Plavšić was a university professor and politician. She was a member of the Serbian Democratic Party (SDS), who became one of two co-Presidents of the Republika Srpska. Being a co-President in 1992 she controlled the armed forces becoming responsible for the implementation of the policy of the forceful ethnic separation. Biljana Plavšić was accused of committing genocide, extermination and murder and persecution on political, racial and religious grounds. She was found guilty of crimes against humanity.

Pauline Nyiramasuhuko, in turn, was a politician and Rwanda's Minister of Family and Women's Development in 1994 during the Rwanda genocides. Similarly, she was accused of inciting to genocide, crimes against humanity and violation of Geneva Conventions [21]. She is known to be the first woman perpetrator of genocide who was actually tried and convicted internationally. Her trial was held by the International Criminal Tribunal for Rwanda (ICTR) in Arusha, Tanzania. 
Having analyzed the discourse used in the trials of those two perpetrators in relation to their social, gender-related roles, the authors [17] stress that their findings:

indicate that it is necessary to recognise a multiplicity of personal, social, cultural and situational factors that might influence women's exercise of agency and women's propensity to engage in violence, including violence committed against other women. Consequently, law's gender neutrality is little more than gender blindness if it does not take account of the social, cultural and personal embodiment of gender practices, including in crime.

The concepts of masculinity and femininity play a very important role in assessing deeds committed by people. It is hard to achieve gender neutrality in discourse as the stereotypical roles and behavior of men and women frequently surface. Furthermore, as women are attributed with sensitivity and motherhood, the crimes committed by them may be perceived as more shocking and condemnable. Indeed, more research is needed in the field of gender neutrality of legal discourse. The sociolinguistic factors may play a very important role in trials and may affect their objectivity and neutrality.

\subsection{Can Genocide Target People of a Specific Profession?}

On 1 September 1939, without declaring war, the territory of Poland was invaded from the west by German troops. On 17 September 1939, the Soviet army attacked from the east. The repressions concerned the entire Polish community, but there were professional groups that were particularly affected by them. The occupiers wanted to eradicate Polishness, so they began with repressing the intelligentsia, e.g. university employees, teachers, priests, lawyers, wealthy landowners. Gwiazdowicz and Matulewska [22] put forward the thesis that foresters were one of the professional groups that were particularly persecuted by the Soviet Union. By analyzing archival materials, they prove that:

- foresters were educated, which, taking into account the illiteracy rate in Europe in the interwar period, made them an intellectual elite in Poland and made them socially and politically dangerous for the occupant,

- they posed a direct threat to the occupant having completed professional military training, excellent weapon use and good knowledge of the area (terrain).

Although it is extremely difficult to determine the exact number of foresters killed by the Soviet torturers due to the fact that information from Russian archives is frequently not available, the available data prove an indisputable genocide. In addition to arresting and murdering foresters, they were also at risk of being transported, often with their families, deep into the USSR to labor camps, where they faced prolonged death of malnutrition, overworking and health devastation. They were used for exceptionally hard work in the forest, harvesting wood, and as a well-educated staff they were able to increase the efficiency of work in the gulags. 
The data presented by the authors show that at least 810 foresters from eastern Poland were murdered, and about 600 were deported deep into the USSR. These data did not include members of the foresters' families. The rule was that high-level (educated) foresters were murdered, and the lower, e.g. gamekeepers, i.e. people after a short training, were transported as workers to work in the forest.

Violation of international agreements and laws, as well as genocide committed by the USSR, would be badly received by the community of many countries, and could also open the ground for compensation claims. That is why the Soviets created a huge mechanism of distorting historical facts and denying genocide through propaganda, which the authors called infodemic.

\subsection{How did the Political System of the State Influence the Ideologization of Law?}

During the period of Stalinism, which took over many countries of Central and Eastern Europe after the Second World War, not only information was developing, but also political repressions aimed at achieving ideological effects. This problem was discussed by Pieprzyca [35], who analyzed the normative acts of criminal law adopted in Poland in the years 1944-1956. It was a period of unprecedented ideologization of the communist system in all its manifestations of everyday life. Of course, this ideologization did not bypass the legal system, including criminal law, which was adapted to the needs of the Polish communist authorities controlled by the USSR.

Piotr Pieprzyca [35] analyzed about 100 legal acts that appeared during this period to find out how Stalinist ideology influenced the repressive nature of the law, which became a tool of political struggle. Moreover, it was noted that ideologization was visible both in the way of editing the texts of criminal law, but also in all parts of normative acts, from the title or preamble to legal provisions, in which it was possible to find political, economic and social values fundamental to the ideology of Stalinism.

After World War II, Poles were forced to adopt a new ideology originating from the Soviet Union, called Stalinism. The defense of the interests of the authorities and communist values forced the creation of an apparatus of repression against people having different political opinions, who were called the "hostile element". Repressive law and strict regulations have been introduced, such as.

Whoever establishes an association aimed at overthrowing the democratic system of the Polish State, or who participates in such an enterprise, manages it, provides it with weapons or provides it with other assistance, shall be punishable by imprisonment or the death penalty. [15]

Restrictive legal provisions and the catalog of crimes against the state grew then to an unprecedented size. Any citizen could be accused of hostility towards the state. This allowed for the introduction of repression and omnipresent control of citizens in political, social and economic life. The normative Polish criminal law of that period presents a country surrounded by enemies, both internal (collaborators) who aim to overthrow the democratic system of the Polish state and external, aiming to deprive 
Poland of independence. The People's Republic of Poland is a country where a critical statement about Stalinist ideology is a crime as serious as murder.

The new criminal legislation turned out to be an extremely effective legal and ideological weapon in the fight against the enemies of the Stalinist system. In the first decade after World War II, about 8,000 death sentences were handed down in Poland. These were people considered to be enemies of the People's Republic of Poland. According to the theory of Marxism-Leninism, every revolution needs victims, and in Poland the victims were all those who refused to accept the power imposed by the USSR and rejected the new regime. The Polish justice system during the Stalinist era served the ideology of the communist regime, so the legal system of the country was in fact a lawless system.

\subsection{The Nuremberg Trial as the Beginning of a New Era in Translation and Interpreting Studies}

After the end of World War II, it is time to settle accounts, estimate losses, but also judge those responsible for this tragedy that befell millions of people around the world. Nuremberg was chosen as the place of the trial, which had a symbolic dimension, because it was in this city that until 1939 the party conventions of the NSDAP (Parteitage) were held, it was also here that the first laws against Jews were announced.

The trial was held before the International Military Tribunal, which was a judicial body established on the initiative of France, the USA, Great Britain and the USSR. The Tribunal proceeded for almost a year from 20 November 1945 to 1 October 1946, and the main goal was to judge 22 dignitaries of the Third Reich, including Hermann Göring, Rudolf Hess, Joachim von Ribbentrop, Albert Speer, Wilhelm Keitel and Hans Frank.

Due to the international composition of the Tribunal and international interest in its work, the trial was interpreted into four languages: English, French, German and Russian. During the trial sessions, headphones were used, with the possibility of switching to any chosen language. Such simultaneous interpreting was an innovative solution for those times, and interpreters played a special role. Their work ensured the correct understanding and presentation of not only words but also emotions and impressions of both the perpetrators and the victims. Indeed, it is precisely the topic on which Nowak-Korcz [33] focuses in her publication. She elaborates on the work of interpreters during the Nuremberg trial.

The Nuremberg trial was of great importance, above all historically and legally, as it laid the foundations for an international justice system that had no precedent in history. The process was also linguistically significant as it marked the beginning of simultaneous interpreting and the modern profession of interpreters. Analyzing the memoirs of "Nuremberg interpreters", the author emphasizes both the linguistic and technical challenges they had to face, as well as the deeply personal struggles that they had to overcome, especially on the psychological and ethical level.

Nowak-Korcz [33] analyzed the memories (publications and documentaries) of interpreters such as Peter Less, Siegfried Ramler, Leon Dostert, Patricia Vander 
Elst, Marie-France Skuncke, Elisabeth Kieffer Heyward, Armand Jacoubovitch, who were responsible for interlingual communication during the Nuremberg trials.

Today, 75 years after those events, the Nuremberg trial is still being cited, commented on and analyzed by historians, lawyers, journalists, but also by translators and interpreters. This was undoubtedly a precedent event in every respect opening many new doors. One of them was the development of innovative interpreting techniques, the transition from consecutive interpreting to simultaneous interpreting, the problem of rendering highly emotional and shocking witness accounts, which affected the translators and interpreters' psyche.

\subsection{A Fair Trial of the Perpetrators of the Rwandan Genocide Depended on the Understanding of the Victims}

In about 100 days, from April to July 1994, Hutu extremists mass murdered the Tutsi population. The blood of innocent victims was flowing all over Rwanda. Neighbors killed their neighbors with machetes, houses were burned, women were raped and then cruelly murdered, children were killed in front of their mothers, victims were mutilated by cutting off their limbs. Up to a million people lost their lives.

The hatred between Tutsi and Hutu grew step by step over the decades, but escalated towards the end of the twentieth century. For instance, in December 1990, the "Kangaroo" newspaper published "Hutu Ten Commandments", which clearly emphasized the disrespect for Tutsi women. More and more often the Hutu propaganda depicted Tutsi women as "sexually seductive 'fifth column' in league with the Hutu enemies" [18]. Such dissemination of hostility took effect during the 1994 conflict, when sexual violence and rape became a weapon of war. The extermination methods were varied and spread in time.

During the conflict, Hutu extremists released hundreds of patients suffering from AIDS from hospitals, and formed them into "rape squads". The intent was to infect and cause a "slow, inexorable death" for their future Tutsi rape victims. Some experts estimate that between 250,000 and 500,000 women were raped during the genocide. [18].

After the conflict ended, it was important to try the perpetrators of the genocide, including Jean-Paul Akayesu. He was a teacher, educational inspector, and politician of the Republican Democratic Movement (MDR). He enjoyed a good reputation and was therefore elected to the prestigious position of "bourgmestre" (mayor) in the Taba commune.

The early days of the genocide that began on 6 April 1994, Akayesu had initially sought to fulfil his mandate to protect the residents in his municipality. However, at a meeting he attended on 18 April with ministers of Rwanda's provisional government, their instructions were categorical: 'Soit vous rangez de notre côté et vous appuyez les tueries ou vous perdez votre position d'autorité.' (Either you side with us and support the killings or you lose your position of authority). [18] 
After this meeting, his attitude changed and he began to incite genocide.

It should be remembered that the trial of Jean-Paul Akayesu has been wildly reported by newspapers. It is also an infamous case of the International Criminal Tribunal for Rwanda (ICTR).

However, with regard to the importance of this trial both as a precedent for subsequent ICTR cases and within the broader context of international jurisprudence, its most significant contribution has undoubtedly been the recognition and prosecution of rape as a means of perpetrating genocide. [18]

An important role in this process was played by the testimonies of the witnesses, which had to be translated and interpreted from their mother tongue, Kinyarwanda, into the language in which the Court was sitting, i.e. English and French. It was the issues of translating and interpreting the victims' testimonies and the sociolinguistic analysis of their statements is presented by Fletcher [18]. Providing a fair and just trial for perpetrators required a good, correct understanding of the victims. This in turn placed a great deal of responsibility on translators and interpreters who might have had trouble not having equivalent terms in other languages. The trial of JeanPaul Akayesu was the first concerning the crime of genocide in Rwanda, hence it marked a new direction not only in the legal aspect, but also in the domain of translation and interpreting.

\section{Conclusions}

To recapitulate, genocide is a long-lasting process. It starts with a small act of verbal bias, and is followed by verbal aggression. Single acts of physical violence frequently occur before the final act of genocide is committed. In order to prevent the crimes of genocide, one must realize that the negativity bias is omnipresent $[37,40]$. Negative emotions and social interactions have a more serious effect on a group of people than neutral or positive ones. The acceptance for negative, discriminatory, humiliating, degrading acts of speech, always results in their escalation. The escalation is the hate speech which is frequently featured by vulgar, dehumanizing, animalizing discourse. What is more, the optimal distinctiveness theory [6]; cf. also [29] indicates that human behavior is driven by two forces that is to say the need to be included in a group, to become a member of group (the need for inclusion) and the need for differentiation (which is the need to show uniqueness and individuality). In the acts of genocide, the need for inclusion in the dominant group forces people to convert from loving, normal human beings into murderous beasts ready to deprive someone of their lives. Research into genocide, its types, stages and aftermaths may help avoid such atrocities in the future. The results of research indicates that proper identification and counteracting of polarization and discrimination at various levels of social interactions may helpful. At the same time, recent results in the domain of cyberbullying and internet aggression (as well as their real-life consequences) indicate that we need to face a new threat in the form of digital media which may be skillfully used to spread hate speech on an unprecedented scale. The intergroup contact theory [2] stresses that in order to counteract prejudice and discrimination at 
the social level, people need to share equal status in a group or society. Next, there must be intergroup cooperation present for which people need common goals. The necessary element making the three first elements to work properly and permanently is the support by social and institutional authorities. Without equal status (which excluded discriminatory treatment for any reason), intergroup cooperation (which is the opposition to classification and polarization of social groups), common goals (which are a unifying factor for any group of people) and the support by social and institutional authorities, the prevention of hate speech and possible genocide may not be possible. What is more, it seems important to investigate the discourse of prejudice and counteracting prejudice [34] to find out the linguistic means of counteracting genocide stages as early as possible. Once the classification into "us" and "them" occurs, one may resort to de-categorization by stressing individualism of human beings and achieving desegregation [7]. The promotion of tolerance is necessary to reclassify "us" and "them" into heterogenous conglomerate of individuals who can identify themselves as "we-the human being".

To sum up, genocide is a multistage, multifaceted process, stretched in time and resulting from prolonged brainwashing. Not a single person may be sued of being susceptible to it, no matter his or her profession, gender, denomination, morals or worldview. It is the field test which proves us human or not. The linguistic analysis of the discourse used at specific stages of genocide process may help identify negative trends occurring in societies which may culminate one day in the form of genocide. The research into the discourse may help identify the danger and prevent such atrocities in the future.

\section{References}

1. Allan, Keith, and Kate Burridge. 2006. Forbidden words. Taboo and the censoring of language. New York: Cambridge University Press.

2. Allport, G.W. 1954. The nature of prejudice. Cambridge, Reading, MA: Addison-Wesley.

3. Bartmiński, Jerzy. 1998. Podstawy lingwistycznych badań nad stereotypem — na przykładzie stereotypu matki”. In Język a kultura. T. 12: Stereotyp jako przedmiot lingwistyki. Teoria, metodologia, analizy empiryczne, eds. Janusz Anusiewicz and Jerzy Bartmiński, 63-83. Wrocław: Towarzystwo Przyjaciół Polonistyki Wrocławskiej.

4. Battistella, Edwin L. 2005. Bad language. Are some words better than others? Oxford: Oxford University Press.

5. Brendan, Kennedy, Drew Kogon, Kris Coombs, Joe Hoover, Christina Park, Gwenyth PortilloWightman, Aida Mostafazadeh, Mohammad Atari, and Morteza Dehghani. 2018. A Typology and Coding Manual for the Study of Hate-Based Rhetoric University of Southern California. (preprint) The Gab Hate Corpus: A Collection of 27 k Posts Annotated for Hate Speech.

6. Brewer, M.B. 1991. The social self: On being the same and different at the same time. Personality and Social Psychology Bulletin 17 (5): 475-482.

7. Brewer, M.B., and N. Miller, eds. 1984. Groups in contact. The psychology of desegregation. London: Academic Press.

8. Buder, Jürgen., Lisa Rabl, Markus Feiks, Mandy Badermann, and Guido Zurstiege. 2021. Does negatively toned language use on social media lead to attitude polarization? Computers in Human Behavior. https://doi.org/10.1016/j.chb.2020.106663.2021.106663.

9. Burleson, Shelley J., and Alberto Giordano. 2016. Spatiality of the stages of genocide: The Armenian case. Genocide Studies and Prevention: An International Journal 10 (3): 6. 
10. Chisholm, June F. 2014. Review of the status of cyberbullying and cyberbullying prevention. Journal of Information Systems Education 25 (1): 77-87.

11. Chlebda, Wojciech. 1998. Stereotyp jako jedność języka, myślenia i działania. In Język a kultura. T. 12: Stereotyp jako przedmiot lingwistyki. Teoria, metodologia, analizy empiryczne, eds. Janusz Anusiewicz and Jerzy Bartmiński, 31-41. Wrocław: Towarzystwo Przyjaciół Polonistyki Wrocławskiej.

12. Churchill, Ward. 1997. A little matter of genocide Holocaust and denial in the Americas 1492 to the present. Sylva: City Lights Books.

13. Convention on the Non-Applicability of Statutory Limitations to War Crimes and Crimes Against Humanity of 26 November 1968.

14. Convention on the Prevention and Punishment of the Crime of Genocide of 9 December 1948

15. Decree of October 30, 1944 on the protection of the State.

16. Donegan, Richard. 2012. Bullying and cyberbullying: History, statistics, law, prevention and analysis. The Elon Journal of Undergraduate Research in Communications 3 (1): 33-42.

17. Ellison, Lyn, and Natalia Szablewska. 2021. Constructing women perpetrators of international crimes: A critical discourse analysis. International Journal for the Semiotics of Law. https://doi. org/10.1007/s11196-020-09728-3.

18. Fletcher, Narelle. 2021. Sociolinguistic challenges of prosecuting rape as genocide at the international criminal tribunal for Rwanda: The trial of Jean-Paul Akayesu. International Journal for the Semiotics of Law 34: 4. https://doi.org/10.1007/s11196-020-09810-w.

19. Flöter-Durr, Margarete. 2012. Le discours de l'authenticité: de l'ensauvagement de la langue l'anéantissement d'autrui. International Journal for the Semiotics of Law. https://doi.org/10. 1007/s11196-020-09779-6.

20. Gagliardone, Iginio, Danit Gal, Thiago Alves, and Gabriela Martinez. 2015. Countering online hate speech. Paris: Unesco Publishing. https://unesdoc.unesco.org/ark:/48223/pf0000233231. Accessed 22 January 2019.

21. Geneva Convention of 27 July 1929 on the treatment of prisoners of war. https://ihl-databases. icrc.org/applic/ihl/ihl.nsf/INTRO/305?OpenDocument. Accessed on 17 January 2020.

22. Gwiazdowicz, Dariusz J., and Aleksandra Matulewska. 2021. Lethal laws and lethal education. A case study of Soviet genocide against Polish foresters and five decades of infodemic. International Journal for the Semiotics of Law. https://doi.org/10.1007/s11196-020-09767-w.

23. Haslam, Nick, and Michelle Stratemeyer. 2016. Recent research on dehumanization. Current Opinion in Psychology 11 (2016): 25-29.

24. Hinduja, Sameer, and Justin W. Patchin. 2008. Cyberbullying: An exploratory analysis of factors related to offending and victimization. Deviant Behavior 29 (2): 129-156. https://doi.org/10. 1080/01639-62070-14578-16.

25. Hu, Lung-Lung. 2021. Justification and opposition of mass killing: Black sun-The nanking massacre. International Journal for the Semiotics of Law. https://doi.org/10.1007/ s11196-020-09791-w.

26. Le Bon, Gustaw. 2006. Psychologia ttumu. Warszawa: Wydawnictwo Naukowe PWN.

27. Lemkin, Raphael. 1944. Axis rule in occupied Europe: Laws of occupation, analysis of government, proposals for redress, 79-95. Washington, DC, New York: Carnegie Endowment for International Peace Division of International Law, Columbia University Press.

28. Lemkin, Raphael. 2008 (reprint). Axis rule in occupied Europe: Laws of occupation, analysis of government, proposals for redress. Clark, New Jersey: The Lawbook Exchange, Ltd.

29. Leonardelli, Geoffrey J., Cynthia L. Pickett, and Marilynn B. Brewer. 2010. Chapter 2-Optimal distinctiveness theory: A framework for social identity, social cognition, and intergroup relations. In Advances in experimental social psychology, vol. 43, ed. Mark P. Zanna and James M. Olson, 63-113. London: Academic Press.

30. Matulewska, A., and D.J. Gwiazdowicz. 2020. "I would kill the director and teachers in the school" cyberbullying of hunters in Poland. International Journal for the Semiotics of Law. https://doi.org/10.1007/s11196-020-09723-8.

31. McEnery, Tony. 2006. Swearing in English. Bad language, purity and power from 1586 to the present. New York: Routledge.

32. Nikitina, Serafina F. 1998. Stereotypy jako bariery kulturowe. In Jezyk a kultura. T. 12: Stereotyp jako przedmiot lingwistyki. Teoria, metodologia, analizy empiryczne, ed. Janusz Anusiewicz and Jerzy Bartmiński, 155-159. Wrocław: Towarzystwo Przyjaciół Polonistyki Wrocławskiej. 
33. Nowak-Korcz, Paulina. 2021. Le génocide des nazis dans les témoignages des interprètes et traducteurs au procès de Nuremberg. International Journal for the Semiotics of Law. https://doi.org/10. 1007/s11196-021-09834-w.

34. Pettigrew, T.F. 1998. Intergroup contact theory. Annual review of psychology 49 (1): 65-85.

35. Pieprzyca, Piotr. 2021. Législation pénale à l'époque stalinienne en Pologne - analyse jurilinguistique. International Journal for the Semiotics of Law. Vol. 34/4

36. Roberts, Celia, Evelyn Davies, and Tom Jupp. 2014. Language and discrimination. Routledge.

37. Rosenberg, Sheri P. 2012. Genocide is a process, not an event. Genocide Studies and Prevention 7 (1): 16-23.

38. Rozin, Paul, and Edward B. Royzman. 2001. Negativity bias, negativity dominance, and contagion. Personality and Social Psychology Review 5 (4): 296-320. https://doi.org/10.1207/S15327957P SPR0504_2.

39. Siemaszko, Andrzej. 1993. Granice tolerancji. O teoriach zachowań dewiacyjnych. Warszawa: Wydawnictwo Naukowe PWN.

40. Skowronski, John J., and Donal E. Carlston. 1987. Social judgment and social memory: The role of cue diagnosticity in negativity, positivity, and extremity biases. Journal of Personality and Social Psychology. 52 (4): 689-699. https://doi.org/10.1037/0022-3514.52.4.689.

41. Stanton, Gregory. 2016. "The ten stages of genocide." Genocide Watch.

42. Wagner, Anne. 2019. E-victimization and e-predation theory as the dominant aggressive communication: The case of cyberbullying. Social Semiotics 29 (3): 303-318.

43. Wagner, Anne and Wei Yu. 2021. Machiavellian apparatus of cyberbullying: Its triggers igniting fury with legal impacts. International Journal for the Semiotics of Law. 34(4).

44. United Nations Declaration on the Rights of Indigenous Peoples (UNDRIP) of 13 September 2007.

45. United Nations General Assembly Resolution 96 of 11 December 1946, titled "The Crime of Genocide".

Publisher's Note Springer Nature remains neutral with regard to jurisdictional claims in published maps and institutional affiliations. 